\section{Asymptomatic bilateral elongated and mineralized stylohyoid complex. Report of one case}

\author{
HELLÍADA CHAVES $^{1}$, FÁBIO COSTA ${ }^{2}$, DANIEL CAVALCANTE ${ }^{3}$, \\ THYCIANA RIBEIRO ${ }^{4}$, DELANE GONDIM ${ }^{1}$
}

\begin{abstract}
The stylohyoid process is a cylindrical bony structure surrounded by important anatomical structures including vessels and nerves. Calcification and elongation of the stylohyoid ligament complex over $30 \mathrm{~mm}$ may be associated with neck and facial pain, known as Eagle's syndrome. However, a bilateral ossified and elongated stylohyoid complex may be devoid of symptoms. We report a 79-year-old symptom-free female who presented on a routine conventional dental radiographic exam an $80.96 \mathrm{~mm}$ pseudoarticulated stylohyoid complex in the left side and an $75.85 \mathrm{~mm}$ on the other. On CAT scan, both processes were calcified.
\end{abstract}

(Rev Med Chile 2013; 141: 793-796).

Key words: Eagle's syndrome; Radiography, panoramic; Tomography, x-ray computed; Temporal bone abnormalities.

\section{Proceso estilohioideo elongado y calcificado asintomático. Presentación de un caso}

El proceso estilohioideo es una estructura ósea rodeada por nervios y vasos sanguíneos. La calcificación elongación del ligamento estilohioideo en más de $30 \mathrm{~mm}$ puede asociarse a dolor facial y del cuello, conocido como sindrome de Eagle. Sin embargo, esta alteración anatómica puede ser asintomática. Presentamos una mujer asintomática de 79 años a quien se le descubrieron procesos estilohioideo pseudo articulado de 80,96 $\mathrm{mm}$ a un lado y 75,85 $\mathrm{mm}$ al otro lado, en una radiografía dental convencional. En la tomografía axial computada, ambos procesos estaban calcificados.

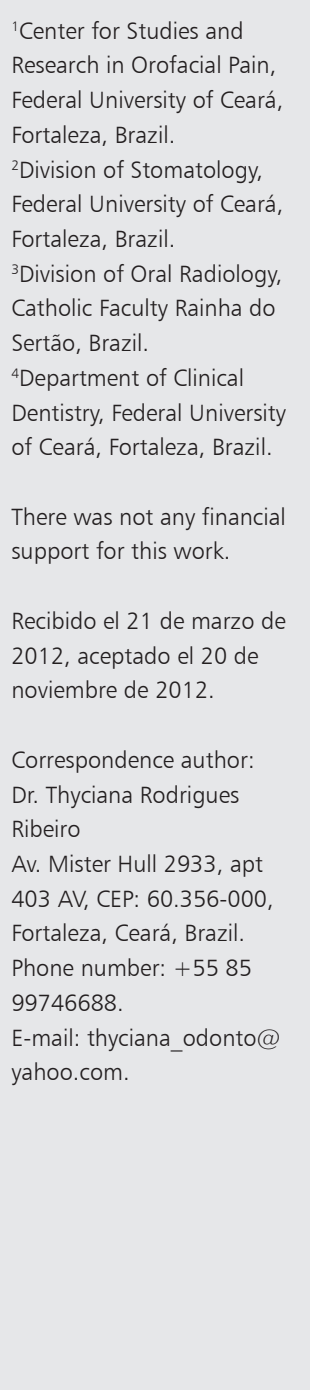

$\mathrm{T}$ he styloid process is a thin cylindrical bony projection that originates from tympanic part of the temporal bone. Stylohyoid complex (SC) is an anatomic structure formed by styloid process, stylohyoid and stylomandibular ligaments, and stylopharyngeus, stylohyoid and styloglossus muscles ${ }^{1}$. Adjacent to SC there are diverse nerves (glossopharyngeal, facial, accessory, hypoglossal, vagus) and vessels (internal jugular vein, internal carotid artery $)^{2}$. Normally, the styloid process is a cylindrical, long cartilaginous bone located on the temporal bone no longer than $30 \mathrm{~mm}^{3}$. However, when the SC assumes large proportions over than $30 \mathrm{~mm}$, it is considered elongated (SCE). Panoramic radiography is useful for detection of an elongated styloid process in patients with or without symptoms ${ }^{4}$. The SCE can be associated to neck and cervicofacial pain which is formerly known as Eagle's syndrome $e^{1-3,5,6}$.

Several reports of Eagle's syndrome are well described in the literature but few cases of symptom-free patients with SC bilaterally elongated and mineralized have been published. Thus, the purpose of this paper was to describe an interesting case of a non-syndromic patient that presented this condition. The present work was approved 
by the Ethics Committee of the University of Vale do Acaraú (protocol \# 808) and the subject gave its informed consent.

\section{Case Report}

A 79-year-old systemically healthy female was referred to the Center for Studies and Research in Orofacial Pain of the Federal University of Ceará Campus Sobral, Brazil, for dental routine exams. Intraoral inspection revealed normal tissues recovering the edentulous alveolar processes. A panoramic radiography was taken as a screening film after the examination. Radiographic imaging showed bilateral elongation and calcification

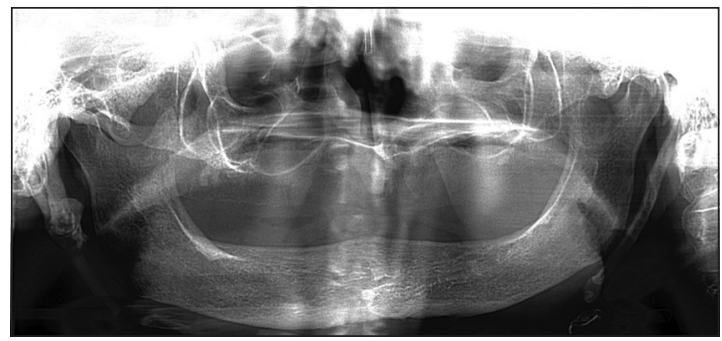

Figure 1. Orthopantomography showing the stylohyoid complex elongated bilaterally. of the SC measuring $75.85 \mathrm{~mm}$ and $80.96 \mathrm{~mm}$ for right and left sides respectively (Figure 1). A three-dimensional computed tomographic (CT) reconstruction showed styloid-stylohyoid complexes were over-elongated from the base of the skull plane down to the hyoid bone, with one pseudoarticulation on the right side and segmentation on both sides and confirmed the diagnosis (Figure 2). To exclude the Eagle's syndrome, the tonsilar fossa and cervicofacial region were palpated and did not produce symptoms. Physical examination of the neck region did not reveal abnormalities and the overlying skin was normal with no cervical lymphadenopathy. Upon clinical evaluation, radiographic features, absence of intraoral painful symptoms or cervicofacial discomfort a diagnosis of SC elongation in a non-Eagle's syndrome patient was supposed. Patient's past medical history showed no evidence of systemic diseases. Due to lack of complaints, a non surgical approach was decided in agreement with the patient and the follow-up was uneventful.

\section{Discussion}

We have presented a remarkable case of SC elongation in a 79-year-old patient, with typical

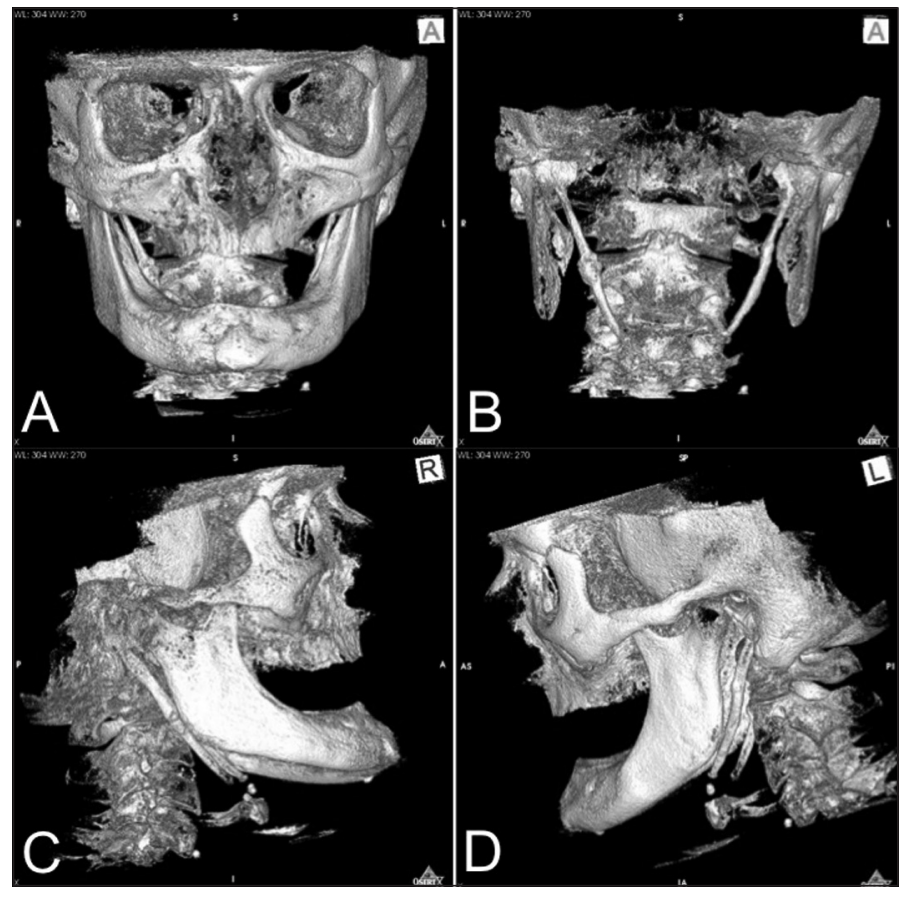

Figure 2. 3D CT showing elongation and ossification of the SC $(\mathbf{A}, \mathbf{B})$ with presence of styloid process pseudoarticulated on the right side (C) and segmentation of the styloid process on the left side (D) 
radiographic features of bilateral involvement and a $75.85 \mathrm{~mm}$ and $80.96 \mathrm{~mm}$ for right and left sides respectively of the SC. According to literature, the average length of the styloid process is less than $30 \mathrm{~mm}$, with the normal length ranging from 15.2 $\mathrm{mm}$ to $47.7 \mathrm{~mm}^{2}$. In a Brazilian study ${ }^{6}$, the mineralization extension varied from $26.1 \mathrm{~mm}$ to $65 \mathrm{~mm}$, which was in disagreement with our report. In addition, this study showed that only $4.4 \%$ of the elderly population presented the styloid process elongated over than $50 \mathrm{~mm}$.

It has been argued that the SC elongation may be due to low-grade stimulus, surgical trauma, menopause, persistence of mesenchymal elements, growth of the osseous tissue, mechanical stress or trauma during development of styloid process, and more recently extraskeletal (ectopic) calcification or ossification ${ }^{3,5}$.

When it becomes elongated, commonly neck and cervicofacial painful symptoms are present probably due to compression of the styloid process on neural and vascular structures, and an Eagle's syndrome is defined ${ }^{1-3,5,6}$. Although unusually, the $\mathrm{SC}$ can assume large proportions without symptoms, as observed in the present case and the one reported by Sisman et $\mathrm{al}^{3}$. The ability of a SC to become an extensive structure and not producing symptoms mainly depends on the relationship of the SC with the adjacent nerves and vessels ${ }^{5}$. As supposed in the current patient, if the styloid process is able to grow with no compression, the condition might remain asymptomatic for a long period of time.

The SC over than $30 \mathrm{~mm}$ can cause craniofacial and cervical pain, difficulties in swallowing, secondary glossopharyngeal neuralgia, throat pain, earache, foreign body sensation in throat, pain on changing head position, headache, shoulder pain, sensation of a lump in the throat, and radiating pain into the orbit and maxillary region ${ }^{7,8}$. An SC elongation may cause symptoms due to compression of the glossopharyngeal, vagus and trigeminal nerves, carotid artery syndrome, hyoid syndrome, or rheumatic styloiditis following pharyngeal infection ${ }^{7,9-11}$.

The Eagle's syndrome is more frequent in female patients, mainly in individuals younger than 30 years ${ }^{8}$. According to Dao et $\mathrm{al}^{12}$, this syndrome may be present in either one of two forms: the "classic Eagle's syndrome", which is commonly observed after tonsillectomy surgery, and sympto- matology similar to cluster headache or migraine due to stimulation of the sympathetic nerve plexus after impingement of the internal or external carotid artery. The diagnosis can usually be made on physical examination by digital palpation of the styloid process in the tonsillar fosse, which exacerbates the pain and with radiographical exams, and injection of an anaesthetic solution into the tonsilar fosse, which relief the symptoms ${ }^{13}$. Surgical approach is usually performed as treatment in affected patients ${ }^{7}$.

Despite of Eagle's syndrome subjects, most asymptomatic patients with elongation of the SC are recognized after routine dental radiographic exams as reported in our case. Langlais et $\mathrm{al}^{7}$, proposed a classification of the radiographic appearance of elongated and mineralized SC based on three types of complexes, including type 1 (uninterrupted styloid image), type 2 (styloid process pseudoarticulated with the ossified stylohyoid or stylomandibular ligament), and type 3 (long or short interrupted portions of the styloid process or discontinuous segments of the mineralized ligament. Furthermore, these complexes types were described by a pattern of calcification: calcified outline partially calcified, nodular, and completely calcified. Our report confirms the presence of a pseudo articulation in an extended styloid process, almost entirely ossified in both sides, which is extremely uncommon ${ }^{2,7}$.

Although orthopantomography is indicated for best visualizing the styloid process, anteroposterior and lateral cefalometric radiography may be valuable ${ }^{2}$. According to Nakamura et $\mathrm{al}^{8}$. In conventional radiographs the overlapping of the submandibular area is prone to partly cover the image of the styloid process; also, in the situations where the stylohyal ligament is not completely calcified, correct diagnosis is not always easy and explanation to the patient can be unimpressive in some cases. We performed a three-dimensional computed tomography (3D CT) to confirm the diagnosis of ossification of the stylohyoid ligament and the other relationship structures. It have been reported that $3 \mathrm{D}$ CT is a suitable exam for defining anatomic associations, correct size, and angulation of the stylohyoid process ${ }^{2}$.

In cases of styloalgia, effective treatment involves surgical excision or reduction of the styloid process, although pharmacological therapy has been employed ${ }^{1}$. For asymptomatic patients, a 
closed follow-up is important due to possibility of Eagle's syndrome development after traumatic events ${ }^{2,3}$.

In conclusion, bilateral elongation and ossification of SC in an asymptomatic patient with pseudoarticulation on the right side and segmentation on both sides, though uncommon, must be included as part of the differential diagnosis for Eagle's syndrome. Our report has confirmed the importance of conventional dental radiographs for initial diagnosis in asymptomatic patients despite recent advanced image approaches. The lack of complaints in our case does not invalidate recommendation for a long-term monitoring, especially when intervening at elderly patients.

\section{References}

1. Kim E, Hansen K, Frizzi J. Eagle syndrome: case report and review of the literature. Ear Nose Throat J 2008; 11: 631-3.

2. Pereira FL, Filho LI, Pavan AJ, Farah GJ, Gonçalves EA, Veltrini VC, et al. Styloid-stylohyoid syndrome: literature review and case report. J Oral Maxillofac Surg 2007; 65: 1346-53.

3. Sisman Y, Gokce C, Sipahioglu M. Bilateral elongated styloid process in an end-stage renal disease patient with peritoneal dialysis: is there any role for ectopic calcification? Eur J Dent 2009; 3: 155-7.

4. More CB, Asrani MK. Evaluation of the styloid process on digital panoramic radiographs. Indian J Radiol Imaging 2010; 20: 261-5.

5. Gokce C, Sisman Y, Sipahioglu M. Styloid process elon- gation or Eagle's syndrome: is there any role for ectopic calcification? Eur J Dent 2008; 2: 224-8.

6. Rizzatti-Barbosa CM, Ribeiro MC, Silva-Concilio LR, Di Hipolito O, Ambrosano GM. Is an elongated stylohyoid process prevalent in the elderly? A radiographic study in a Brazilian population. Gerodontol 2005; 22: 112-5.

7. Prasad KC, Kamath MP, Reddy KJ, Raju K, Agarwal S. Elongated styloid process (Eagle's syndrome): a clinical study. J Oral Maxillofac Surg 2002; 60: 171-5.

8. Uysal IO, Atalar MH, Kosar MI, Durmus K. Elongated styloid process associated with nevoid basal cell carcinoma syndrome. J Craniofac Surg 2011; 22: 2132-4.

9. Harma R. Stylagia: Clinical experiences of 52 cases. Acta Otolaryngol 1967; 224: 149.

10. Moffat DA, Ramsden RT, Shaw HJ. The styloid process syndrome: aetiological factors and surgical management. J Laryngol Otol 1977; 91: 279-94.

11. Strauss M, Zohar Y, Laurian N. Elongated styloid process syndrome: intraoral versus external approach for styloid surgery. Laryngoscope 1985; 95: 976-9.

12. Dao A, Karnezis S, Lane JS 3rd, Fujitani RM, Saremi F. Eagle syndrome presenting with external carotid artery pseudoaneurysm. Emerg Radiol 2011; 18: 263-5.

13. Prabhu LV, Kumar A, Nayak SR, Pai MM, Vadgaonkar R, Krishnamurthy A, Madhan Kumar SJ. An unusually lengthy styloid process. Singapore Med J 2007; 48: e34-6.

14. Langlais RP, Miles DA, Van Dis ML. Elongated and mineralized stylohyoid ligament complex: a proposed classification and report of a case of Eagle's syndrome. Oral Surg Oral Med Oral 1986; 61: 527-32.

15. Nakamura Y, Fukuda S, Miyashita S, Ohashi M. Diagnosis of the elongated styloid process by three-dimensional computed tomography. Auris Nasus Larynx 2002; 29: $55-7$. 